\title{
ALGAL DIVERSITY IN MIDSTREAM OF THE ACHANKOVIL RIVER DURING MONSOON AND POST MONSOON SEASON
}

\author{
Meera Krishnan ${ }^{*}$, Praveen Dhar Thulasidas ${ }^{* *}$, Sreejai Raghavan ${ }^{* *}$, Sreeja Thankappan ${ }^{* * *}$ \\ * University of Kerala, Mahatma Gandhi College, Thiruvananthapuram, Kerala, India \\ ** University of Kerala, St. Stephen's College, Pathanapuram, Kollam, Kerala, India \\ *** University of Kerala, Nair Service Society College, Nilamel, Kollam, Kerala, India
}

corresponding author: Praveen Dhar Thulasidas, e-mail: dharpraveent@gmail.com

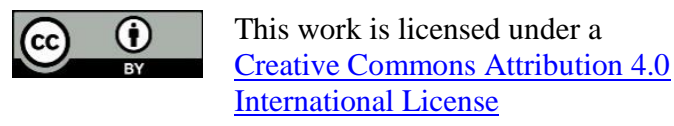

Professional paper

Internationa License

Received: April $6^{\text {th }}, 2020$

Accepted: May $4^{\text {th }}, 2020$

HAE-1949

https://doi.org/10.33765/thate.11.1.3

\begin{abstract}
Algae are simple organisms whose size ranges from microscopic to macroscopic large seaweeds over thirty meters long. The study examined the algal diversity in the midstream of the Achankovil River. Pandalm is located in the central point of the Achankovil River. Water samples were collected during the monsoon and post monsoon seasons. Samples were collected in the early morning; phytoplanktonic forms were gathered by plankton net. The exploration identified the presence of 41 algal genera pertaining to the classes of Chlorophyceae, Bacillariyophyceae, Cyanophyceae and Euglenophyceae. The pollution-indicating species increased in post monsoon season in comparison to monsoon season of the river and larger numbers of algal species are reported during monsoon season.
\end{abstract}

Keywords: algal diversity, Achankovil River, pre and post monsoon season

\section{INTRODUCTION}

Algae belong to the kingdom of Protista and their size varies from the microscopic to macroscopic. Algae are diverse life forms, found almost everywhere on the planet. They take a central position in many ecosystems and play a pivotal role in balancing the biotic and abiotic components. Algae are the primary producers in aquatic ecosystem and form essential components of the food web; they may have an important role in maintaining the equilibrium between living and non-living factors [1]. Algae capture more amount of the solar energy and release more oxygen than green plants. The algal diversity in an ecosystem is determined by the level of richness of species and their functional importance in ecosystem, depending upon the seasons the algae appear and disappear [2]. Algal diversity researches are useful for the assessment of the water body type and quality [3]. The Achankovil River is an important fresh water resource in Kerala, located in the southern tip of the peninsula and originating from Western Ghats and it enriches Pathananmthitta District of the Kerala state. The river is $128 \mathrm{~km}$ long and bounded with 
thick flora and fauna on both banks. The river joins with the Pamba River at the place called Veeyapuram of the Alappuzha District of Kerala. Sabarimala is a prominent pilgrimage centre in India, approximately 45 - 50 million devotees come to visit during the pilgrimage season, which starts in November and ends in January. Pandalam is the encampment of this popular pilgrim centre, situated relatively close to the Achankovil River. Pilgrims use the water resources of Achankovil River for various hygienic purposes. The present research was undertaken to assess the richness of microscopic and macroscopic algal diversity in the mid part of the Achankovil River during monsoon and post monsoon seasons.

\section{EXPERIMENTAL}

Water samples used for the analysis were collected from different midstream zones of the Achankovil River, comprising Pandalam valiyakoikkal temple kadavu, Kaipuzha Sree Krishnan temple kadavu, and Mahadeva temple kadavu (Figure 1).
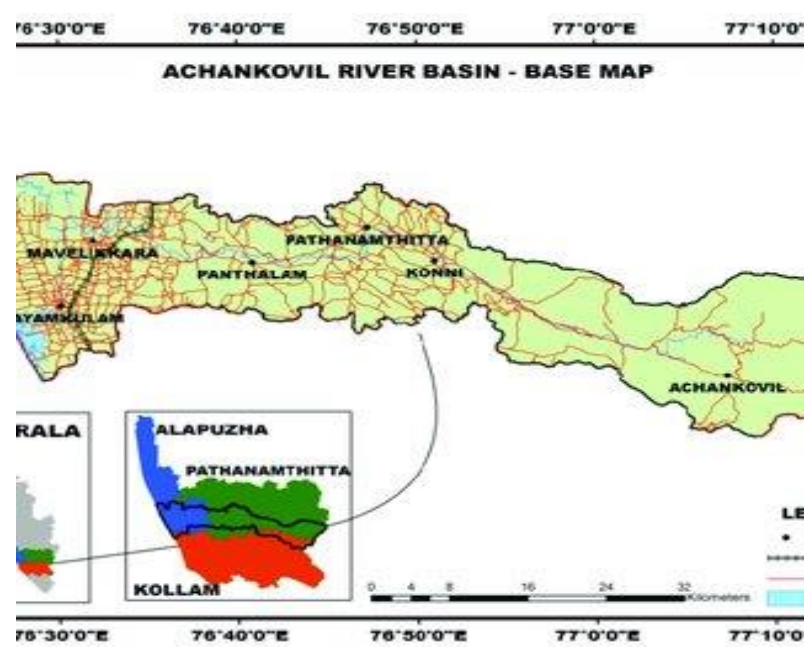

Figure 1. Sampling location

The water samples were collected during the monsoon season (November - January) and post monsoon season (June - September) 2018 - 2019. Minimum of five sampling stations were selected from each zone to make the study more reliable. Samples were collected during the early morning before the day break. Phytoplanktonic forms were collected with plankton net Number-20 silk bolting cloth with the mesh size of $20 \mu \mathrm{m}$. Sediments were also collected using Van Veen Grab for the algal species that live in or on these sediments [4]. Collected samples having phytoplanktons were allowed to settle by adding Lugol's Iodine and $4 \%$ of formalin. Macro algae and attached forms were gathered manually. Microscopic observations were carried out with Magnus (MX21i Clinical) light compound microscope and photographed algae were identified with the help of fresh water algal identification key [5 - 7].

\section{RESULTS AND DISCUSSION}

The current research work has been intended to explore the algal diversity of the Achankovil River during monsoon and post monsoon seasons. The results of the investigation revealed the presence of 41 algal genera belonging to the classes of Chlorophyceae, Bacillariyophyceae, Cyanophyceae, and Euglenophyceae. Among the 41 algal genera, 27 algae were recorded in post monsoon season and 35 during the monsoon or pilgrim season. The members of the Chlorophyceae class dominated with 16 genera, followed by Bacillariophyceae with 15 genera, the genera belonging to Cyanophyceae were represented by 7 and Euglenophyceae by 3 items (Table 1). The presence of pollution indicating species increased in monsoon or pilgrim season. The presence of Euglena indicated the abundance of decaying organic materials for algal growth [8]. The presence of pollution tolerant algae like Melosira, Oscillatoria, Pediastrum and Scenedesmus is considered as an indicative of enriched water, thus providing evidence of water pollution [9]. Pinnularia gibba, Cymbella, Nitzschia and Navicula are indicators which act as the source of organic as well as anthropogenic pollution [10]. 
Table 1. Seasonal algal diversity in the midstream of the Achankovil River

\begin{tabular}{|c|c|c|c|}
\hline Algal Class & Algal genera and species & Post-monsoon season & Monsoon season \\
\hline \multirow{16}{*}{ Chlorophyceae } & Cosmarium candianum & - & + \\
\hline & Cosmarium manipurense & + & + \\
\hline & Scenedesmus quadricauda & - & + \\
\hline & Chlorella & + & + \\
\hline & Chlorococcum & + & + \\
\hline & Closterium acutum & + & - \\
\hline & Euastrum & + & + \\
\hline & Nephrocytium & + & - \\
\hline & Mougeotia & - & + \\
\hline & Closteriopsis & - & + \\
\hline & Gonatozygon & - & + \\
\hline & Selenastrum & - & + \\
\hline & Odogonium & + & + \\
\hline & Pediastrum boryanum & + & + \\
\hline & Pediastrum tetras & - & + \\
\hline & Ankistrodes musconvolutus & + & - \\
\hline \multirow{15}{*}{ Bacillariophyceae } & Cocconeis & + & + \\
\hline & Cymbella & + & + \\
\hline & Gomphonema & + & + \\
\hline & Gyrosigma & + & + \\
\hline & Navicula pupula & + & - \\
\hline & Navicula hasta & + & + \\
\hline & Navicula mutica & + & + \\
\hline & Nitzschia & + & + \\
\hline & Pinnularia gibba & + & + \\
\hline & Pleurosgma & + & - \\
\hline & Surirellar obusta & + & + \\
\hline & Syndra ulna & + & + \\
\hline & Tabellaria flocculosa & + & - \\
\hline & Fragilaria & - & + \\
\hline & Melosira & + & + \\
\hline \multirow{7}{*}{ Cyanophyceae } & Oscillatoria ornate & + & + \\
\hline & Oscillatoria agardhii & - & + \\
\hline & Oscillatoria annae & + & + \\
\hline & Lyngbya majuscule & - & + \\
\hline & Lyngbya arboricola & - & + \\
\hline & Anabaena & - & + \\
\hline & Gloeocapsa & + & + \\
\hline \multirow{3}{*}{ Euglenophyceae } & Euglena & - & + \\
\hline & Phacus & + & + \\
\hline & Trachelomonas & - & + \\
\hline
\end{tabular}

\section{CONCLUSION}

The investigation on algal diversity of the midstream areas of the Achankovil River revealed the existence of 4 groups. Among these 4 groups, Chlorophyceae were dominant over all other groups. Euglenophyceae were the least present, i.e. only 3 species. Related research findings previously reported that Euglenophyceae were more present in polluted water and distribution varied according to seasons and physico-chemical parameters of water. The present study concludes that water of the Achankovil River is polluted due to contaminations, especially during the monsoon season. 


\section{REFERENCES}

[1] S.B. Hulyal, B.B. Kaliwal, Dynamics of phytoplankton in relation to physicochemical factors of Almatti reservoir, Environmental Monitoring Assessment 153(2009), 45-59.

[2] P. Arulmurugan, S. Nagaraj, N. Anand, Biodiversity of fresh water algae from Guindy Campus of Chennai, Indian Journal of Ecobiotechnology 3(2011) 10, 19-29.

[3] S.K. Pawar, J.S. Palle, K.M. Shendge, The study on phytoplankton of Pethwadaj Dam, Taluka, Kandhar, Maharashtra, Journal of Aquatic Biology 21(2006) 1, 1-6.

[4] APHA, Standard methods for the examination of water and waste water. $20^{\text {th }}$ Edition, American Public Health Association, American Water Works Association and Water Environmental Federation, Washington DC, 1998.

[5] T.V. Desikachary, ICAR monograph on algae, $1^{\text {st }}$ Edition, Indian Council of Agricultural Research, New Delhi, India, 1959.

[6] G.W. Prescott, Algae of the Western Great lakes Areas, Otto Koeltz Science Publishers, Germany, 1982.

[7] M.T. Philipose, Freshwater plankton of Inland fisheries, $1^{\text {st }}$ Edition, Indian Council of Agricultural Research, New Delhi, 1967.

[8] E. Girish Kumar, K.V. Thanzeeha, K. Sasikala, G. Pradeepkumar, K.K. Sivadasan, V. Jaleel Abdul, A Preliminary Study on the Diversity of Planktonic Algae of Kaanam River, Kannur, Kerala, India, Phykos 48(2011) 2, 13-16.

[9] P.P. Tessy, R. Sreekumar, A report on the pollution algae from the Thrissur Kol wetlands (part of Vembanad Kol, Ramsar site), Kerala, Nature Environment Pollution Technology 7(2008) 2, 311-314.

[10] C.M. Palmer, A composite ratting of algae tolerating organic pollution, Journal of Phycology 5 (1969), 78-82. 